\title{
25. GEOCHEMICAL EVIDENCE FOR FLUID FLOW AND DIAGENESIS AT THE CASCADIA CONVERGENT MARGIN ${ }^{1}$
}

\author{
Miriam Kastner, ${ }^{2}$ James C. Sample, ${ }^{3}$ Michael J. Whiticar, ${ }^{4}$ Martin Hovland, ${ }^{5}$ Barry A. Cragg, ${ }^{6}$ and John R. Parkes ${ }^{6}$
}

\begin{abstract}
Pervasive fluid advection is indicated in the geochemical depth profiles at four locations (five sites), two in the Vancouver Island (VI) sector and two in the Central Oregon (CO) sector of the Cascadia Convergent Margin. Diffusive fluid flow prevails at the VI Sites 888 and $889 / 890$, whereas confined fluid flow dominates the CO Sites 891 and 892 . Exactly the same deepseated fluid source $(>1.5$ to $<4 \mathrm{~km}$ ) was found in both areas, regardless of the fluid-flow regime. It is characterized by lower than seawater $\mathrm{Cl}$ concentration, higher than seawater $\mathrm{Li}, \mathrm{Ca}, \mathrm{Sr}$, and silica concentrations, non-radiogenic $\mathrm{Sr}$ isotopes and is slightly depleted in ${ }^{18} \mathrm{O}$. The upward-advecting fluid that transports thermogenic hydrocarbons mixes with the pore fluids altered by diagenesis. The extent of mixing between these fluids varies spatially.

At the CO sector of the Cascadia Margin where confined fluid flow prevails, the frontal thrust at Site 891 is presently not acting as a significant, but only as a leaky, fluid conduit, in contrast to the landward-dipping fault at Site 892 .

Organic matter-fueled diagenesis dominates over the depth-range drilled. An inverse relationship between sedimentation rate and both total organic carbon content (TOC) and the sulfate reduction rate is characteristic of this convergent margin. An important result of the bacterial degradation of organic matter is a widespread formation of diagenetic carbonates. The upwardmigrating fluid that is enriched in $\mathrm{Ca}$, dissolved inorganic carbonate, and thermogenic hydrocarbons most likely favors the formation of epigenetic carbonates.

Although solid gas hydrate was not recovered at the depth of either of the prominent bottom-simulating reflectors (BSRs), their presence is inferred from geochemical (and geophysical) measurements. The geochemistry, particularly the coincidence between pore fluids that have very low $\mathrm{Cl}$ concentrations and very high methane concentrations at these depths, indicates that primarily a methane hydrate occupies at least $15 \%$ of the pore space above the BSR at the VI Site 889 , and at least $10 \%$ of the pore space above the BSR at the CO Site 892 . The solid gas hydrate recovered at $\sim 2$ to 19 mbsf, Site 892 , is a mixed $\mathrm{CH}_{4}-\mathrm{H}_{2} \mathrm{~S}$ hydrate of which up to $10 \%$ of the gas is $\mathrm{H}_{2} \mathrm{~S}$.
\end{abstract}

\section{INTRODUCTION}

That fluids affect virtually all aspects of the geologic evolution of convergent margins has been well established (e.g., Shipley et al., 1979; Bray and Karig, 1985; Kulm et al., 1986; Carson et al., 1990; Moore et al., 1990; Kastner et al., 1991). Prior to Leg 146, most attention was given to surficial manifestations of confined fluid venting in the $\mathrm{CO}$ sector of the margin, which supports benthic communities and is associated with mud volcanoes, diapirs, and widespread carbonate deposition (e.g., Kulm et al., 1986; Ritger et al., 1987; Moore et al., 1990; Carson et al., 1990, 1994). Information about fluid expulsion by diffusive-flow through porosity reduction by tectonic compaction, deformation, and thermal mineral dehydration and transformation processes was provided through seismic studies of arcward thinning of the sediment sections, by mapping the distribution of carbonate crusts, and by studies of the physical and thermal states of the sediments (e.g., Hyndman and Davis, 1992; Moore et al., 1990; Cochrane et al., 1994; Tobin et al., 1994; Carson et al., 1994). On the basis of these studies the main objectives for drilling four locations (five sites) at the Cascadia Convergent Margin, Ocean Drilling Program (ODP) Leg 146, were (1) to document the fluid-flow

'Carson, B., Westbrook, G.K., Musgrave, R.J., and Suess, E. (Eds.), 1995. Proc. ODP, Sci. Results, 146 (Pt. 1): College Station, TX (Ocean Drilling Program).

${ }^{2}$ Scripps Institution of Oceanography, 0212, University of California, San Diego, La Jolla, CA 92093, U.S.A.

'Department of Geological Sciences, California State University, Long Beach, CA 90840, U.S.A.

${ }^{4}$ School for Earth and Ocean Sciences, University of Victoria, Victoria, British Columbia V8W 2Y2, Canada.

s Statoil, P.O. Box 300, N-4001 Stavanger, Norway.

${ }^{6}$ Department of Geology, University of Bristol, Bristol BS8 IRJ, United Kingdom. regimes and investigate the tectonic and geochemical consequences of diffusive vs. confined fluid flow; (2) to assess the importance of each of these fluid-flow regimes; (3) to unravel the fluid origin(s); and (4) to examine the nature and origin of the prominent bottomsimulating reflectors (BSRs) observed at this margin. Objectives 1 and 3 are particularly emphasized in this synthesis.

Sites 888 and $889 / 890$ are located at the Vancouver Island (VI) sector, and Sites 891 and 892 at the Central Oregon (CO) sector of the Cascadia Convergent Margin (Fig. 1). Their distinct geologic settings are discussed, for example, in Hyndman and Davis (1992) and West-

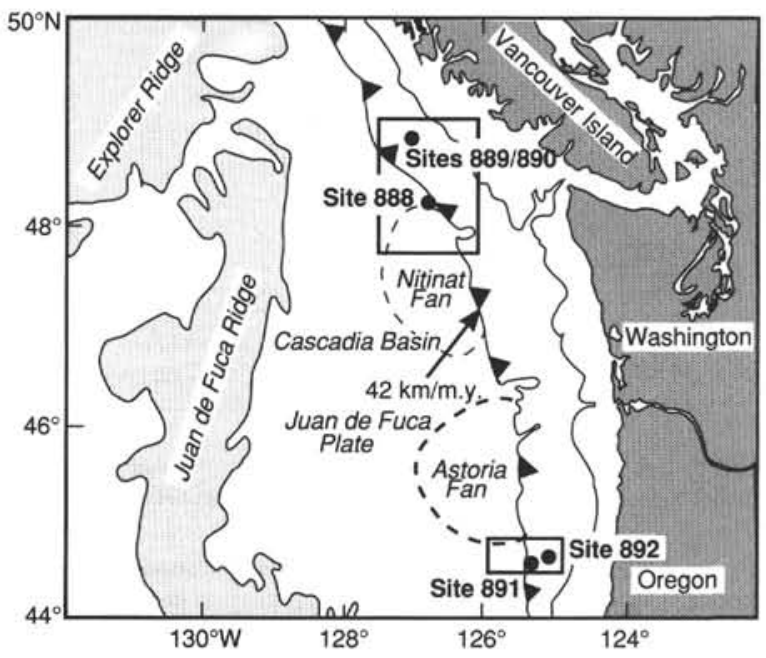

Figure 1. Location of Cascadia margin sites drilled on ODP Leg 146. From Westbrook, Carson, Musgrave, et al. (1994). 
Table 1. Geologic data for drilled Cascadia Margin sites, Leg 146.

\begin{tabular}{|c|c|c|c|c|c|c|c|c|c|}
\hline \multirow[b]{2}{*}{ Site } & \multirow[b]{2}{*}{ Location } & \multirow{2}{*}{$\begin{array}{l}\text { Sediment } \\
\text { thickness } \\
\text { cored } \\
\text { (m) }\end{array}$} & \multirow[b]{2}{*}{ Sediment composition } & \multirow[b]{2}{*}{ Age of sediment } & \multirow{2}{*}{$\begin{array}{c}\text { Average } \\
\text { sedimentation } \\
\text { rate } \\
(\mathrm{m} / \mathrm{m} . \mathrm{y} .)\end{array}$} & \multirow{2}{*}{$\begin{array}{l}\text { Geothermal } \\
\text { gradient } \\
\left({ }^{\circ} \mathrm{C} / \mathrm{km}\right)\end{array}$} & \multicolumn{2}{|c|}{ TOC (wt\%) } & \multirow{2}{*}{$\begin{array}{l}\text { Minimum } \\
\text { depth of } \\
\text { total } \mathrm{SO}_{4} \\
\text { reduction } \\
\text { (mbsf) }\end{array}$} \\
\hline & & & & & & & range & average & \\
\hline 888 & $\begin{array}{l}\text { Cascadia Basin, at northern } \\
\text { edge of Nitinat Fan }\end{array}$ & 567 & $\begin{array}{l}\text { Clayey silt with fine to } \\
\text { coarse sand }\end{array}$ & $\begin{array}{l}\text { Late Pleistocene-Holocene } \\
\quad(<0.8 \mathrm{Ma})\end{array}$ & -800 & 68 & $0.1-0.6$ & 0.3 & -220 \\
\hline $889 / 890$ & $\begin{array}{l}\text { Mid-slope off Vancouver } \\
\text { Island margin }\end{array}$ & 389 & Clayey silt with fine sand & $\begin{array}{l}\text { Late Pliocene-late } \\
\text { Quaternary }\end{array}$ & $<100$ & 54 & $0.2-1.3$ & 0.9 & $\sim 10$ \\
\hline 891 & $\begin{array}{l}\text { Lowermost ridge off central } \\
\text { Oregon continental slope }\end{array}$ & 472 & $\begin{array}{l}\text { Clayey silt with fine to } \\
\text { medium sand }\end{array}$ & Late Quaternary $(<0.8 \mathrm{Ma})$ & -600 & ? & $0.1-0.8$ & 0.2 & $\sim 200$ \\
\hline 892 & $\begin{array}{l}\text { Top of second ridge off } \\
\text { central Oregon continental } \\
\text { slope }\end{array}$ & 177 & Clayey silt with fine sand & Early to late Pliocene & $\begin{array}{l}\sim 200 \text { (hiatuses and } \\
\text { stratigraphic } \\
\text { inversions present) }\end{array}$ & 51 & $0.9-1.9$ & 1.5 & $<20$ \\
\hline
\end{tabular}

Note: data from Westbrook, Carson, and Musgrave, et al. (1994).

brook, Carson, Musgrave, et al. (1994). At the sites drilled, the ratio of turbiditic to hemipelagic sediments varies in space and time, and the porosities of the 200 - to 600 -m-thick sediment sections drilled decrease from $\sim 80 \%$ to $\leq 40 \%$ (Westbrook, Carson, Musgrave, et al., 1994). The locations of the sites and several of their important distinctive characteristics are summarized in Table 1. Although the VI sector is characterized by diffusive fluid flow, and the CO sector by confined fluid flow along faults, fractures or stratigraphic conduits, as suggested by Kulm et al. (1986), Ritger et al. (1987), Kulm and Suess (1990), Moore et al. (1990), and Carson et al. (1990, 1994), at both margin sectors prominent reversed polarity BSRs exist (Hyndman and Davis, 1992; Westbrook, Carson, Musgrave, et al., 1994; MacKay et al., 1994).

The following geochemical synthesis is based on shipboard and shore-based geochemical results (Westbrook, Carson, Musgrave, et al., 1994; Kastner and Elderfield, this volume; Kastner et al., this volume). It provides new information on the geochemical manifestations of two types of fluid-flow regimes, diffusive and confined, and new insights on diagenesis and fluid source(s) at two sectors of the Cascadia Convergent Margin. The nature and origin of the prominent BSRs associated with the two fluid-flow regimes, and the origin of the $\mathrm{CH}_{4}-\mathrm{H}_{2} \mathrm{~S}$ gas hydrate recovered at 2 to 19 mbsf at Site 892, are briefly discussed. Detailed discussions of BSRs and gas hydrates are given in Kastner et al. (this volume), and Kastner et al. (unpubl. data).

\section{METHODS}

The methods used for the shipboard geochemical analyses are given in Westbrook, Carson, Musgrave, et al. (1994); those for the shore-based chemical and isotopic analyses are provided in Kastner and Elderfield (this volume).

The isotopic data are reported in parts per thousand (per mil, \%o) enrichment or depletion relative to a standard, and defined as:

$$
\delta \times(\% o)=\left(\frac{R_{x}}{R_{s t d}}-1\right) \times 10^{3}
$$

where $\mathrm{R}_{\mathrm{X}}$ represents the isotope ratio of a sample (i.e., $\mathrm{D} / \mathrm{H},{ }^{13} \mathrm{C} /{ }^{12} \mathrm{C}$, ${ }^{18} \mathrm{O} /{ }^{16} \mathrm{O},{ }^{34} \mathrm{~S} /{ }^{32} \mathrm{~S}$ ), and $\mathrm{R}_{\text {std }}$ is the corresponding ratio in a standard.

The standard for the fluids oxygen and hydrogen isotopes is Standard Mean Ocean Water (SMOW) (Craig, 1961); for carbon isotopes is PeeDee Formation Belemnite (PDB); and for sulfur isotopes is troilite $(\mathrm{FeS})$ of the iron meteorite Canyon Diablo.

The strontium isotopes are reported as the ratio ${ }^{87} \mathrm{Sr} /{ }^{86} \mathrm{Sr}$. The data were normalized to ${ }^{86} \mathrm{Sr} /{ }^{87} \mathrm{Sr}=0.1194$, and the value obtained for the National Bureau of Standards (NBS) No. 987 is 0.710255 at the Scripps Institution of Oceanography (SIO) laboratory. For seawater the value is 0.709175 with a $2 \sigma$ uncertainty of $\pm 18 \times 10^{-6}$.

\section{RESULTS AND DISCUSSION \\ Evidence for Fluid Flow and Sources}

Pore-fluid chemical concentration and isotopic-ratio depth profiles are most effective for recognizing transient or steady-state fluid flow and for identifying fluid source(s). Other important valuable manifestations of fluid flow are: (1) the presence of thermogenic hydrocarbons that could not have been generated in situ, and, therefore, must have migrated from elsewhere; (2) non-linear thermal gradients; and (3) non-sedimentation-controlled porosity reversals.

In addition to the distribution and isotopic composition of the hydrocarbons, discussed in Westbrook, Carson, Musgrave, et al. (1994) and in Whiticar et al. (this volume), the most distinctive geochemical parameters that indicate the origin of the fluids and the nature of fluid flow, at two sectors of the Cascadia Margin, are the pore fluids $\mathrm{Cl}, \mathrm{Li}$, and $\mathrm{Sr}$ concentrations, and their $\mathrm{Sr}$ and oxygen isotopic compositions, discussed below.

\section{Chloride $(\mathrm{Cl})$ Concentrations}

Chloride is assumed to behave conservatively during diagenesis and metamorphism. It will be diluted by either hydrous silicates dehydration and transformation reactions or by gas hydrate dissociation. It is concentrated by the formation of hydrous phases, including gas hydrate. The distinction between different reactions that change the $\mathrm{Cl}$ concentration is possible by analyzing multiple chemical components and normalizing their concentrations to that of $\mathrm{Cl}$. $\mathrm{Cl}$ dilution from gas hydrate dissociation would not shift any of the normalizedto-Cl profiles; in contrast, dilution from silicate dehydration would. Shifts after normalization-to- $\mathrm{Cl}$ concentration would be recognizable, especially in the silica, $\mathrm{K}$, and $\mathrm{Na}$ depth profiles.

Particularly at Site 892, the $\mathrm{Cl}$ concentration-depth profile shows distinct non-steady-state characteristics suggesting fluid flow (Fig. 2). At Site $888, \mathrm{Cl}$ concentrations provide evidence for confined fluid flow at $\sim 70$ and $\sim 540$ mbsf that is probably stratigraphically controlled; at Site 891 , below the non-diffusional boundary at $\sim 200$ mbsf, the $\mathrm{Cl}$ concentrations do not vary considerably with depth, except for a few non-distinct confined fluid-flow horizons. The frontal thrust was intersected at $\sim 367 \mathrm{mbsf}$, which, although presently not very active, is not dormant: the $\mathrm{Cl}$ concentration is not distinct, but maxima in thermogenic hydrocarbon concentrations were documented at this depth interval (Westbrook, Carson, Musgrave, et al., 1994), and the $\mathrm{Sr}$ - isotope values, discussed below, also indicate some recent flow activity along it. A strong active low- $\mathrm{Cl}$ fluid conduit exists at $\sim 130 \mathrm{mbsf}$ at Site 889 . It is enriched in $\mathrm{Ca}, \mathrm{K}, \mathrm{Si}$, and in alkalinity (Westbrook, Carson, Musgrave, et al., 1994), which suggests that it is fed by a fluid that originates at least a few hundred meters deeper, where dehydration of hydrous silicates occurs. The length of the diffusional path, between it and the sediment/seawater interface, indi- 


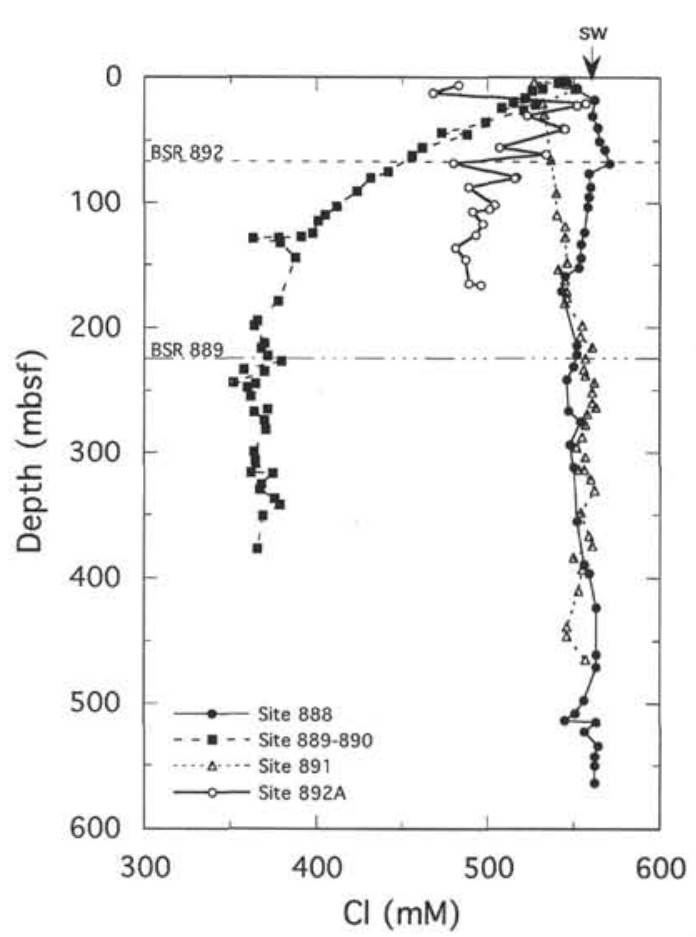

Figure 2. Depth profiles for $\mathrm{Cl}$ concentrations in pore fluids of Sites 888 , $889 / 890,891$, and 892. The arrow indicates seawater (SW) concentration (data from Westbrook, Carson, Musgrave, et al., 1994).

cates that this stratigraphically controlled conduit has been active for at least $1.5 \times 10^{5}$ years. It seems to be a barrier for the vertical migration of thermogenic hydrocarbons that are present only below it (Westbrook, Carson, Musgrave, et al., 1994; Whiticar et al., this volume). Chloride dilution of up to $36 \%$ of seawater $\mathrm{Cl}$ value dominates the Site 889 concentration-depth profile below the $\sim 130$ mbsf active conduit, especially below $\sim 200$ mbsf through the prominent BSR at $224 \mathrm{mbsf}$ to the bottom of the cored interval at this site. This diluted $(362 \pm 10 \mathrm{mM} \mathrm{Cl})$ pore fluid has a mixed origin. It consists of the in situ pore fluid, diluted by the dissociated modern gas hydrate above the BSR and by the paleo-gas hydrate below the BSR. It is modified by the upward-migrating (through tectonic compaction) low-Cl fluid from $>1.5 \mathrm{~km}$ depth, as indicated by the Li concentrations, $\mathrm{Sr}$, and oxygen isotope ratios of the pore fluids, and by the presence of thermogenic hydrocarbons throughout this depth interval (Kastner et al., this volume; Westbrook, Carson, Musgrave, et al., 1994). Dilution through mixing with meteoric water is not supported by the geologic setting, and the membrane ion filtration process is being excluded as an important process because of its extremely low efficiency vis-avis the extreme $\mathrm{Cl}$ dilution at this site.

The distinct non-steady-state $\mathrm{Cl}$ concentration-depth profile, above the BSR at Site 892 , is caused by gas hydrate dissociation along specific narrow sedimentological horizons (Kastner et al., this volume), and below the BSR by advective flow of a low- $\mathrm{Cl}$ fluid from a deeper source. This fluid migrates along fracture and fault zones (Westbrook, Carson, Musgrave, et al., 1994) and carries thermogenic hydrocarbons (Whiticar et al., this volume). Furthermore, distinct thermal anomalies associated with two of these thrust faults exist: one occurs at the depth of the BSR, at $~ 68 \mathrm{mbsf}$, and the second at the intersection with the hydrologically active landward-dipping fault, between $\sim 105$ and 120 mbsf. Flow along this thrust fault is thermally significant enough to cause the shallowing of the base of the hydrate stability (and BSR) (Westbrook, Carson, Musgrave, et al., 1994)

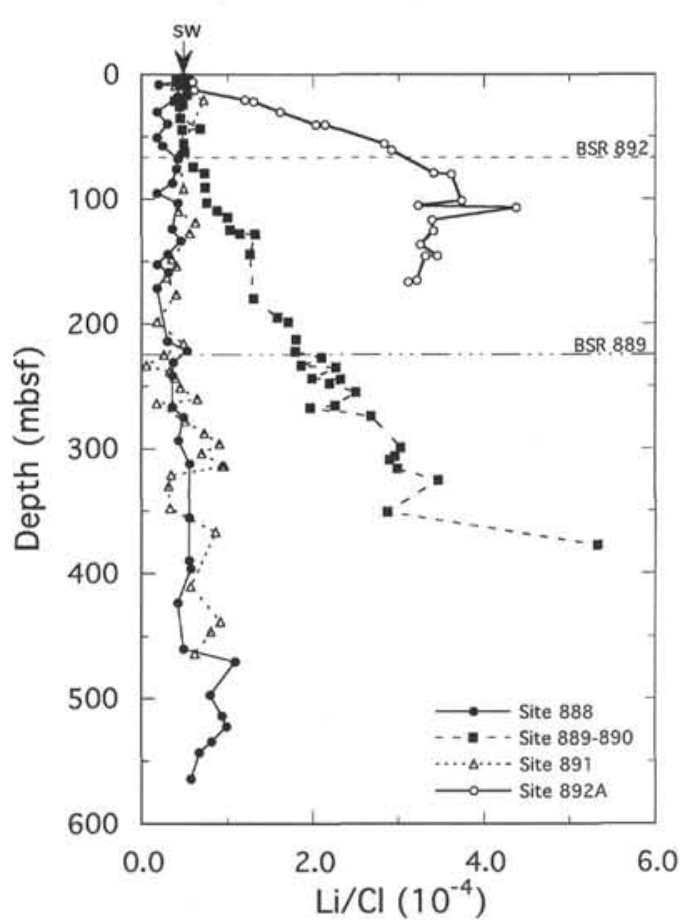

Figure 3. Depth profiles for $\mathrm{Li} / \mathrm{Cl}$ ratios in pore fluids from Sites 888,889 / 890,891 , and 892 . The arrow indicates seawater (SW) concentration (data reported in Kastner and Elderfield, this volume).

\section{Lithium (Li) and Strontium (Sr) Concentrations.}

The pore fluids of all sites were analyzed for Li concentrations, because $\mathrm{Li}$ is the most mobile alkali ion; aluminosilicates are its main source. The geochemical mobility of Li is strongly temperature-dependent. At low temperatures, $\mathrm{Li}$ is partitioned into clay minerals during volcanic matter alteration and other silicate diagenetic reactions. At moderate to high temperatures, fluid-rock reaction $\mathrm{Li}$ is leached out of silicates, and is thus remobilized and concentrated in the fluid phase (e.g., Edmond et al., 1979; Seyfried et al., 1984).

The crossover temperature is as yet undetermined. Field and laboratory observations suggest that the cross-over temperature is between $70^{\circ}-100^{\circ} \mathrm{C}$ (Edmond et al., 1979; Seyfried et al., 1984; Martin et al., 1991). Accordingly, at the regional geothermal gradients of $51^{\circ}$ to $68^{\circ} \mathrm{C} / \mathrm{km}$ (Table 1), in situ leaching of $\mathrm{Li}$ will commence at $>1 \mathrm{~km}$ burial depth. Higher than seawater $\mathrm{Li}$ concentrations in pore fluids at $<1 \mathrm{~km}$ burial depth would thus indicate fluid migration from a deeper source.

The $\mathrm{Li} / \mathrm{Cl}$ ratio depth profiles of Figure 3 thus show that a Li-enriched fluid, which must have originated from a minimum burial depth of $\geq 1 \mathrm{~km}$, is evidently present at each of the Cascadia Margin sites, but is found most distinctly at Sites $889 / 890$ and 892 . The Lirich fluid must have migrated vertically regionally, driven by tectonic compaction. At the higher sedimentation-rate VI Site 888, its influence is observed only below $470 \mathrm{mbsf}$, and, at the CO Site 891, it is observed locally at $\sim 300$ and below $\sim 370$ mbsf. At the slower sedimentation-rate VI Site $889 / 890$, dissolved $\mathrm{Li}$ has permeated the section to the depth of the $\sim 130$ mbsf fluid conduit. The fluid of this conduit is also somewhat enriched in $\mathrm{Li}$, suggesting a nonlocal source for it. At the CO Site 892, the Li-rich fluid has permeated the whole section.

On the basis of the $\mathrm{Li} / \mathrm{Cl}$ ratio depth profile of Site 889, except for the $\sim 130$ mbsf conduit, there is no evidence for confined fluid flow 


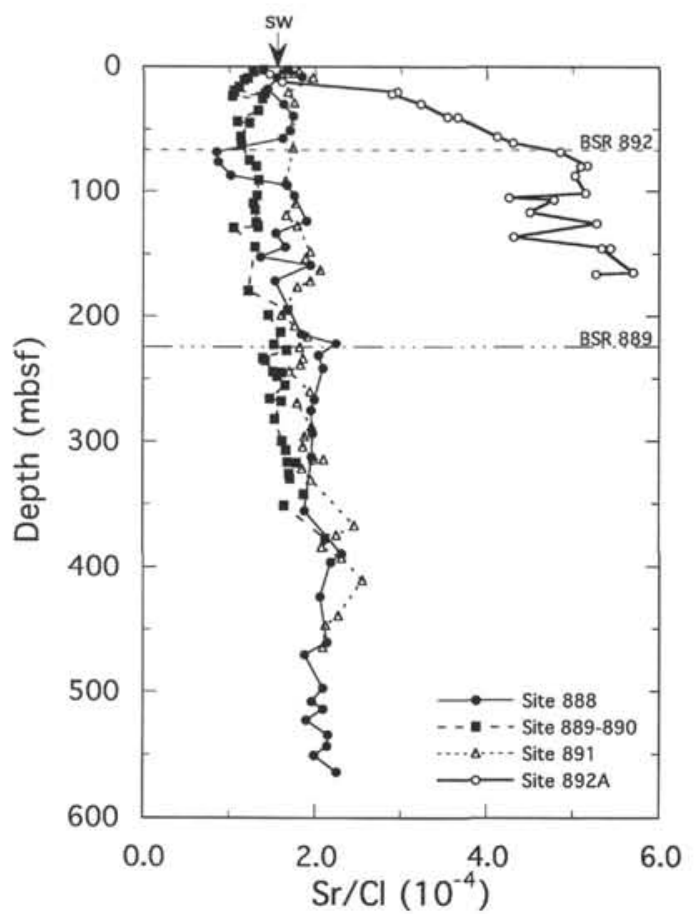

Figure 4. Depth profiles for $\mathrm{Sr} / \mathrm{Cl}$ ratios in pore fluids from Sites 888,889 / 890,891 , and 892 . The arrow indicates seawater (SW) concentration (data reported in Kastner and Elderfield, this volume).

CO sites imply the dominance of fault and fracture-controlled fluid flow. At Site 891 , below $\sim 220 \mathrm{mbsf}$, Li concentrations are generally low, and they vary irregularly with depth. The strongest concentration maxima occur at $\sim 310$ and $\sim 367$ mbsf; at these intervals thermogenic hydrocarbon concentrations are also elevated (Westbrook, Carson, Musgrave, et al., 1994). Site 892 has the most striking $\mathrm{Li} / \mathrm{Cl}$ depth profile, with a pronounced maximum at the intersection with the landward-dipping fault at $\sim 105$ to $120 \mathrm{mbsf}$. Below the $\sim 68 \mathrm{mbsf}$ $\mathrm{BSR}, \mathrm{Li}$ concentrations are higher than the seawater concentration by a factor of $>7$, indicating the intense and important influence fluid flow has on the geochemistry at this site and, similarly, below $\sim 280$ mbsf at Site 889/890 (Fig. 3). At Site 891, the frontal thrust, although leaky, presently is not acting as a significant fluid conduit, in contrast to the landward-dipping fault at Site 892 .

The dissolved $\mathrm{Sr}$ concentration signature is more complex than that of the $\mathrm{Li}$ concentration, because, unlike $\mathrm{Li}, \mathrm{Sr}$ is strongly involved in both aluminosilicate and carbonate reactions. At low temperatures $\mathrm{Sr}$ is consumed by both volcanic matter alteration products and carbonate authigenesis. At moderate to elevated temperatures $\mathrm{Sr}$ is released by the dissolution of aluminosilicates; moreover, volcanic matter and aluminosilicates rapidly (geologically) exchange $\mathrm{Sr}$ isotopes with the associated fluid. The release of $\mathrm{Sr}$ from carbonates is dependent on temperature, pressure, and $\mathrm{pH}$, which control carbonate dissolution, recrystallization and decarbonation.

Determining $\mathrm{Sr}$ concentrations of pore fluids is exceptionally important permitting the construction of mixing diagrams involving both $\mathrm{Sr}$ concentrations and isotopes.

The $\mathrm{Sr} / \mathrm{Cl}$ ratio-depth profiles of Figure 4 reemphasize the geochemical uniqueness of Site 892 . At all other sites, the $\mathrm{Sr} / \mathrm{Cl}$ ratios only slightly increase with depth. The fact an increase is observed despite some loss of $\mathrm{Sr}$ through the formation of authigenic carbonates, widespread at Sites $889 / 890,891$ and 892 , suggests that the upwardmigrating deeper-seated source fluid is more extensively enriched in dissolved $\mathrm{Sr}$ than the concentrations in the pore fluids analyzed.

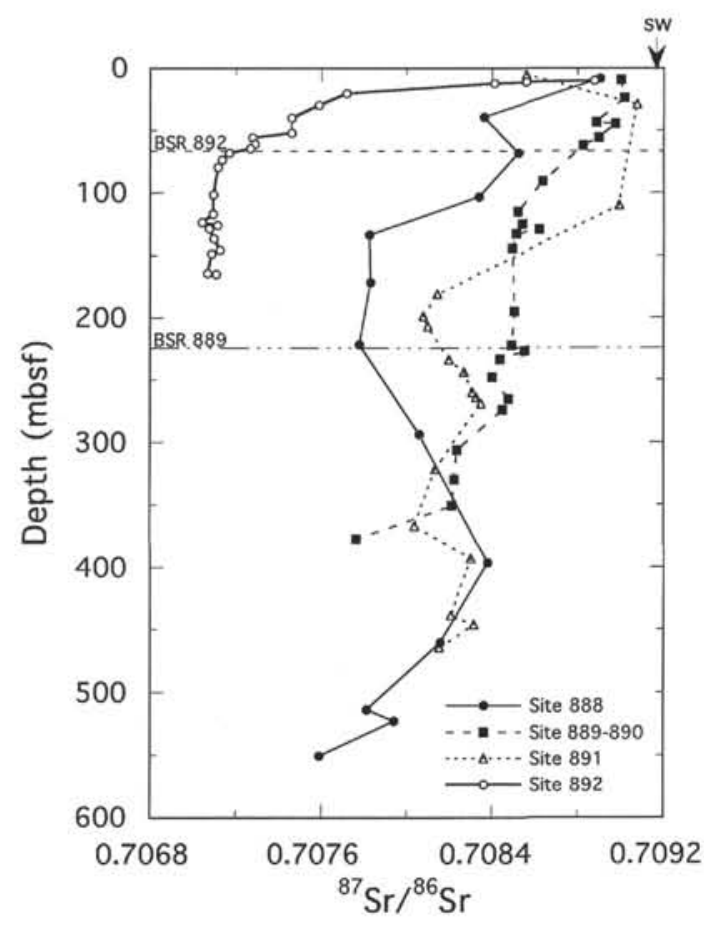

Figure 5. Depth profiles for strontium isotope ratios in pore fluids from Sites $888,889 / 890,891$, and 892 . The arrow indicates seawater (SW) isotopic ratio (data reported in Kastner and Elderfield, this volume).

\section{Strontium Isotope Ratios}

Strontium isotopes do not readily fractionate during diagenesis and metamorphism but readily exchange during fluid-rock reactions. Therefore, they are of great importance for unraveling the sources and sinks of $\mathrm{Sr}$ and, thus, for detecting fluid sources and mixing.

The important features that characterize the pore fluid $\mathrm{Sr}$-isotope ratios shown in Figure 5 are:

1. At all sites, the Sr-isotope values even of the shallowest samples analyzed, are lower than the modern or contemporaneous seawater value, except for one sample at Site 890 that has the modern seawater Sr-isotope value. (Kastner and Elderfield, this volume).

2. At all sites, the ${ }^{87} \mathrm{Sr} /{ }^{86} \mathrm{Sr}$ ratios generally decrease and become less radiogenic, with depth.

3. The ${ }^{87} \mathrm{Sr} /{ }^{86} \mathrm{Sr}$ ratios depth profiles of Sites 888,891 , and 892 are distinctly non-steady-state profiles.

4. The ${ }^{87} \mathrm{Sr} /{ }^{86} \mathrm{Sr}$ ratios and chloride depth profiles are mostly decoupled (Figs. 5 and 2).

The ${ }^{87} \mathrm{Sr} /{ }^{86} \mathrm{Sr}$ ratios of the pore fluids range from the modern seawater value of $0.709175 \pm 22(2 \sigma)$ to 0.707043 at Site 892 . For comparison, the ${ }^{87} \mathrm{Sr} /{ }^{86} \mathrm{Sr}$ value of late Pliocene seawater was 0.709046 at $2.01 \mathrm{Ma}$, and 0.709042 at $3.02 \mathrm{Ma}$ (Hodell et al., 1990).

Evaluation of possible fluid sources may be made through the use of a mixing diagram between $\mathrm{Sr}$ concentration and $\mathrm{Sr}$ isotopic composition (Fig. 6A, B). Two end-member mixing diagrams between seawater and a second source are described by a linear plot of ${ }^{87} \mathrm{Sr} /$ ${ }^{86} \mathrm{Sr}$ vs. $1 / \mathrm{Sr}$ concentration. The most striking feature observed in Figure $6 \mathrm{~A}, \mathrm{~B}$ is that, except for the significantly fresher than seawater pore fluids (the low-Cl fluids) that mainly occur at Site 889 and in the uppermost $\sim 20 \mathrm{~m}$ at Site 892 , almost all data fall on straight mixing 
A

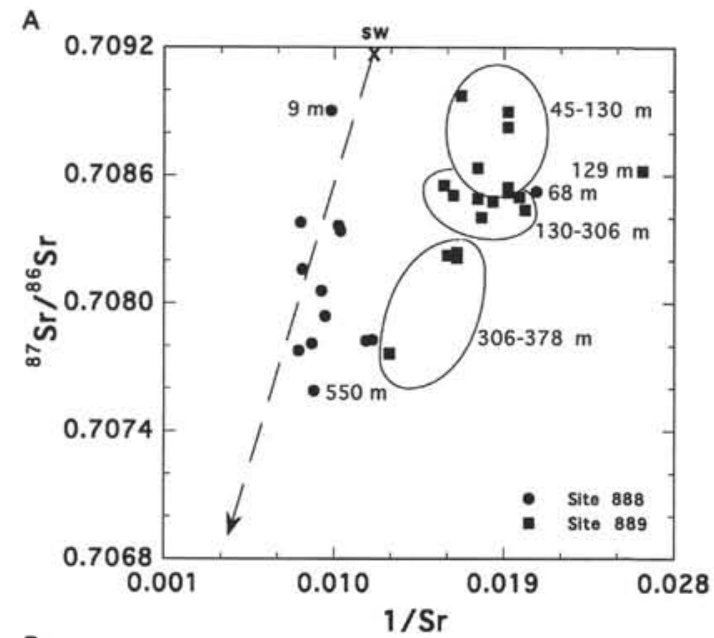

B

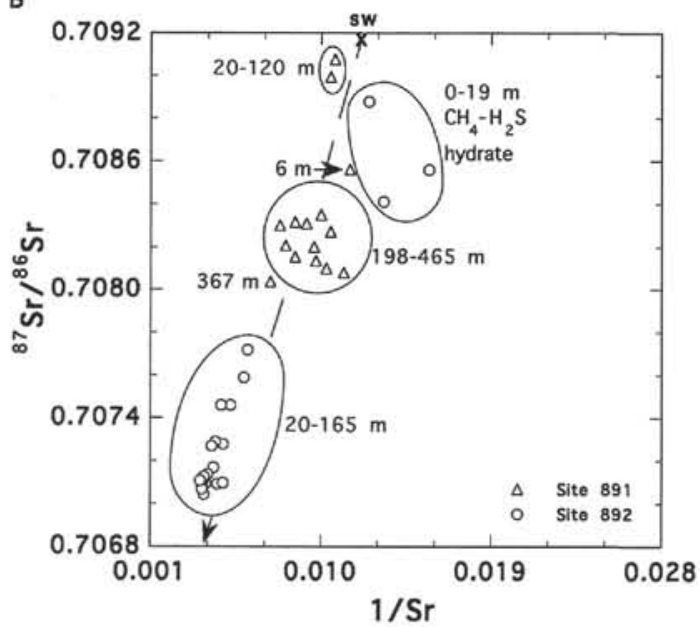

Figure 6. Mixing relationships between ${ }^{87} \mathrm{Sr} /{ }^{86} \mathrm{Sr}$ ratios and $1 / \mathrm{Sr}$ concentrations for (A) VI Sites 888 and 889, and for (B) CO Sites 891 and 892. The $\times$ indicates seawater.

lines representing two $\mathrm{Sr}$ sources, defined by the dashed arrows in Figure 6A, B. Both dashed arrows extend from seawater to a depth corresponding to a $\mathrm{Sr}$ concentration of $\sim 300 \mu \mathrm{M}(1 / \mathrm{Sr}=0.0035)$; also and, most important, the arrows in Figure $6 \mathrm{~A}, \mathrm{~B}$ have exactly the same slope. This indicates that the same deeper source-fluid endmember, enriched in dissolved $\mathrm{Sr}$ and having a considerably non-radiogenic $\mathrm{Sr}$-isotope ratio, mixes with the sediment pore fluids of both $\mathrm{VI}$ and $\mathrm{CO}$ sectors of the Cascadia Margin. By normalizing the $\mathrm{Sr}$ concentrations to $\mathrm{Cl}$ concentrations, the low- $\mathrm{Cl}$ fluids of Sites 889 and those associated with the $\mathrm{CH}_{4}-\mathrm{H}_{2} \mathrm{~S}$ hydrate at Site 892 , also converge on the mixing lines of Figure $6 \mathrm{~A}, \mathrm{~B}$.

In order to examine whether the pore fluids have acquired their $\mathrm{Sr}$ isotopic signature through in situ reactions with the sediments, instead of by mixing with the non-radiogenic, deeper source fluid, a number of sediment samples from three of the sites were analyzed for their $\mathrm{Sr}$ isotopic composition. Before the analysis, the carbonate minerals were carefully removed in order to obtain the sediment silicates' ${ }^{87} \mathrm{Sr} /{ }^{86} \mathrm{Sr}$ ratios. The results in Table 2 show that most of the bulk sediments analyzed are considerably more, not less, radiogenic than even modern seawater, indicating that the data of Figure 6 are not compatible with equilibration of the pore fluids with the associated sediments. Mixing with a fluid from a deeper source, (that is, either volcanic-rich or one that has interacted with basement) is thus implied.
Table 2. Strontium-isotope ratios of carbonate-free bulk sediments, Leg 146 Sites 889,891 , and 892 .

\begin{tabular}{|c|c|c|c|}
\hline $\begin{array}{l}\text { Core, section, } \\
\text { interval }(\mathrm{cm})\end{array}$ & $\begin{array}{l}\text { Depth } \\
\text { (mbsf) }\end{array}$ & ${ }^{87} \mathrm{Sr} /{ }^{86} \mathrm{Sr}$ & $2 \sigma$ \\
\hline $\begin{array}{l}146-889 \mathrm{~A}- \\
18 \mathrm{X}-4,36-46 \\
24 \mathrm{X}-1,34-38 \\
24 \mathrm{X}-1,34-38 \\
24 \mathrm{X}-5,120-140 \\
26 \mathrm{X}-1,42-46 \\
28 X-4,80-100\end{array}$ & $\begin{array}{l}145 \\
188 \\
188 \\
195 \\
207 \\
223\end{array}$ & $\begin{array}{l}0.708142 \\
0.709256 \\
0.709249 \\
0.711300 \\
0.711201 \\
0.709065\end{array}$ & $\begin{array}{l}17 \\
18 \\
15 \\
15 \\
18 \\
15\end{array}$ \\
\hline $\begin{array}{l}146-889 \mathrm{~B}- \\
\quad 15 \mathrm{R}-1,66-69\end{array}$ & 325 & 0.706983 & 16 \\
\hline $\begin{array}{l}\text { 146-891B- } \\
31 X-1,135-150 \\
34 X-1,100-115 \\
35 X-1,16-28\end{array}$ & $\begin{array}{l}244 \\
264 \\
269\end{array}$ & $\begin{array}{l}0.712370 \\
0.710013 \\
0.712868\end{array}$ & $\begin{array}{l}18 \\
17 \\
18\end{array}$ \\
\hline $\begin{array}{l}146-892 \mathrm{~A}- \\
12 \mathrm{X}-1,44-46\end{array}$ & 88 & 0.707167 & 16 \\
\hline $\begin{array}{l}146-892 \mathrm{D}- \\
5 \mathrm{X}-2,8-13\end{array}$ & 148 & 0.707630 & 17 \\
\hline
\end{tabular}

The ${ }^{87} \mathrm{Sr} /{ }^{86} \mathrm{Sr}$ ratio and $\mathrm{Sr}$ concentration of the frontal thrust porefluid sample (the 367-mbsf sample at Site 891), clearly indicate active fluid flow along it, which, however, is non-vigorous. In order to maintain the geochemical signatures at $367 \mathrm{mbsf}$, the fault is either presently an active fluid conduit or has been one in the recent past; the flow rate must be on the order of a few $\mathrm{mm} /$ year. This pore fluid has the least radiogenic ${ }^{87} \mathrm{Sr} /{ }^{86} \mathrm{Sr}$ ratio and the highest $\mathrm{Sr}$ concentration at Site 891; even the deepest fluid analyzed from this site at 465 $\mathrm{mbsf}$ is more radiogenic and less enriched in $\mathrm{Sr}$ (Fig. 6B). In view of the fact that the frontal thrust is connected with the décollement (Westbrook, Carson, Musgrave, et al., 1994), it is suggested that the deeper source fluid, common to all sites, is the fluid flowing along the décollement.

The position of the 6 mbsf pore fluid sample of Site 891, in Figure $6 \mathrm{~B}$ between the $20-120$ and the $198-465 \mathrm{mbsf}$ clusters of data points, provides further evidence for the prevalence of confined fluid flow at this CO site. This fluid sample, from just $6 \mathrm{~m}$ below the sediment/seawater interface, contains a higher fraction of the deeper seated fluid source than the underlying samples from 20 to 120 mbsf, suggesting active fluid venting at the seafloor at this site. The other pore-fluid geochemical data of this sample (i.e., the $\mathrm{Ca} / \mathrm{Cl}$ ratio, $\mathrm{Li}$ concentration, and others) support this conclusion.

In summary, the most salient result is that the pore fluids at both sectors of the Cascadia Convergent Margin, the Vancouver Island and Central Oregon, sectors drilled during Leg 146, communicate with the same deep-seated fluid source, which most probably is situated along the décollement.

\section{Oxygen Isotope Ratios}

Assuming thermodynamic equilibrium, fractionation of oxygen isotopes between water and minerals is dependent on temperature and mineral chemistry. In the marine environment at the sediment/ seawater interface, the oxygen isotope value of the pore water is primarily equal to that of bottom water. Upon burial, pore waters interact with the sediments at increasing temperatures and decreasing porosities, which are altering the water/rock ratios (W/R). At diagenetic and low-grade metamorphic temperatures, reactions proceed through dissolution-precipitation, so the oxygen isotope values of the authigenic precipitates will reflect both the temperature of formation and the isotopic composition of the pore water from which they precipitate. Although depending on the crystal chemistry of the authigenic precipitates, generally below $200^{\circ}$ to $250^{\circ} \mathrm{C}$, the mineral is enriched in ${ }^{18} \mathrm{O}$ relative to the water. However, above $200^{\circ}$ to $250^{\circ} \mathrm{C}$ this relationship reverses (Lawrence et al., 1975). Consequently, at 


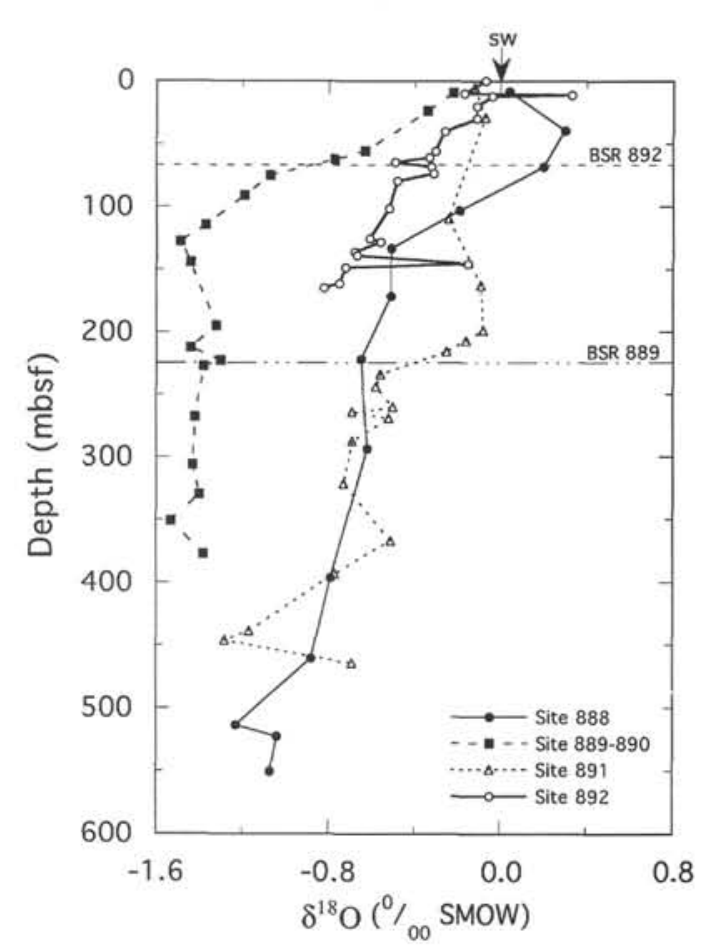

Figure 7. Depth profiles for oxygen isotope ratios in pore fluids from Sites $888,889 / 890,891$, and 892 . The arrow indicates seawater (SW) isotopic ratio (data reported in Kastner and Elderfield, this volume).

shallow to moderate burial depths and average geothermal gradients, pore waters are mostly depleted in ${ }^{18} \mathrm{O}$ relative to seawater. In deep burial and/or high geothermal gradient settings, pore and formation waters will become isotopically heavier, enriched in ${ }^{18} \mathrm{O}$ relative to seawater. Also, at lower W/R ratios, less reaction is required per unit isotopic shift.

The oxygen isotope ratio-depth profiles of Figure 7 indicate that oxygen isotope ratios at all sites are depleted relative to SMOW. Exceptions are the localized positive excursion near the surface of Site 892 , caused by the dissociation of the $\mathrm{CH}_{4}-\mathrm{H}_{2} \mathrm{~S}$ gas hydrate, the localized negative excursion at Site 889 at the depth of the $130 \mathrm{mbsf}$ fluid conduit, and the broad maximum of about $+0.3 \%$ SMOW centered at $\sim 50$ mbsf at Site 888 .

At the prevailing geothermal gradient of $50^{\circ}-70^{\circ} \mathrm{C}$, and assuming a low to moderate W/R ratio at depth, these data suggest that the oxygen isotope value of the deep-source fluid is only slightly depleted relative to SMOW. This implies that the temperature at the fluidsource site is $150^{\circ} \pm 50^{\circ} \mathrm{C}$, which corresponds to a burial depth of $\sim 2$ to $<4 \mathrm{~km}$.

The distinctly lighter oxygen-isotope ratio of the 130 mbsf fluid conduit at Site 889 suggests a shallower origin than that of the deeper source fluid. Because it has been active for over 150,000 years, it has influenced the oxygen isotopic composition of the pore fluids to 250 mbsf. The "spiky" nature of the depth profile in the vicinity of the BSR (Fig. 7) results from gas hydrate dissociation upon core recovery. Because gas hydrate does not fractionate extensively oxygen isotopes, the fractionation is about $+2.7 \%$ (SMOW) (Craig and Hom, 1968; Davidson et al., 1983), and the dissociation of gas hydrate, which occupies $\geq 15 \%$ of the pore space, will cause a relatively small oxygen isotopes shift in the pore fluid, of $<0.5 \%$ at $~ 50 \%$ porosity.

\section{Organic Matter-fueled Diagenesis}

Diagenetic reactions, especially those fueled by organic matter, commonly modify the chemical and isotopic compositions of the pore fluids significantly. They also cause the formation of authigenic minerals and influence oceanic geochemical mass balances. The authigenic precipitates such as carbonates, which often record the geochemical modifications, alter the physical properties of the sediments and, thus, the hydrology. For example, a diffusive flow regime may evolve into a confined one as a result of extensive cementation and hydro-fracturing. In non-advective environments, sedimentation rate is an especially important property. It influences the nature and extent of diagenesis by controlling the depth of diffusional communication with the overlying seawater and the dilution and/or preservation of the sediment components, thus influencing the burial efficiency of organic matter (e.g., Müller and Suess, 1979). Additional important parameters affecting organic matter-fueled diagenesis are (1) the type of organic matter, and (2) the geothermal gradient that determines the depth distribution of bacterial and/or thermogenic organic matter remineralization reactions. The geothermal gradients and total organic carbon (TOC) contents at the sites drilled are summarized in Table 1. At the moderate regional geothermal gradients of $51^{\circ}$ to $68^{\circ} \mathrm{C} / \mathrm{km}$, (Westbrook, Carson, Musgrave, et al., 1994), bacterial-controlled organic matter reactions prevail in situ within the depth intervals drilled at the Cascadia Margin sites. The presence of thermogenic hydrocarbons (Whiticar et al., this volume) thus indicates fluid advection from calculable minimum depths.

Although average sedimentation rates are high at all sites, they are 3 to 8 times higher at Sites 888 (VI) and 891 (CO) than at Sites 889/ 890 (VI) and 892 (CO). The nature of fluid flow is, however, independent of the sedimentation rate. Of special interest is the observed inverse relationships between sedimentation rate and both, TOC content and the rate of sulfate reduction (Table 1, Fig. 8A), caused by dilution with coarser grained turbiditic material that contains refractory organic material. At the two higher sedimentation-rate Sites 888 (VI) and 891 (CO), dissolved sulfate persists to a depth of $\sim 200 \mathrm{mbsf}$, whereas at the slower sedimentation rate Sites $889 / 890$ and 892 , dissolved sulfate is totally reduced bacterially within the uppermost 10 $20 \mathrm{mbsf}$, and TOC content is higher (Westbrook, Carson, Musgrave, et al., 1994) (Fig 8A, Table 1). The $\sim 10 \mathrm{~m}$ interval with zero dissolved sulfate concentration, accompanied by elevated concentrations of alkalinity and headspace methane at $~ 90$ mbsf at Site 888 , is probably a sediment slump (Fig. 8A, B). Following the classical sequence of bacterial activity (e.g., Claypool and Kaplan, 1974; Reeburgh, 1982) methane concentrations increase rapidly and exponentially at the base of the sulfate reduction zone at all sites (Westbrook, Carson, Musgrave, et al., 1994). This is clearly manifested in the depth profiles of dissolved inorganic C (DIC) $\delta^{13} \mathrm{C}$ values, given in Whiticar et al. (this volume), and of bacterial populations distribution, described in Cragg et al., (this volume). Hence, whereas the $\delta^{13} \mathrm{C}$ values across growth zones of authigenic carbonates in principle would permit to reconstruct the $\delta^{13} \mathrm{C}$ depth profiles of DIC, those of bulk authigenic carbonates may be difficult to interpret.

Most sulfide produced by sulfate reduction rapidly reacts with remobilized dissolved ferrous iron, to form di- and/or mono-iron sulfides, especially pyrite and/or greigite; the latter has unique magnetic properties. Even though some of the sulfide may combine with organic matter compounds, the rest diffuses into seawater.

Another important consequence of bacterially mediated organic matter diagenesis (hence sulfate reduction) is carbonate alkalinity production. At all sites alkalinity values are significantly higher than the average seawater value $(\sim 2.4 \mathrm{mM})$. Although an overall inverse relationship between the concentrations of dissolved sulfate and alkalinity exists (Fig. 8A, B), alkalinity values are significantly higher in the uppermost $200 \mathrm{mbsf}$ of the sediment sections at the VI Sites 888 and $889 / 890$, which are characterized by mostly diffusive fluid flow, than at the CO Sites $(891,892)$ characterized by mostly confined fluid flow. Below this depth, however, alkalinity values are similar at both sectors of the Cascadia Margin, and, generally, they decrease with depth. Considering the intense sulfate reduction at Site 892 

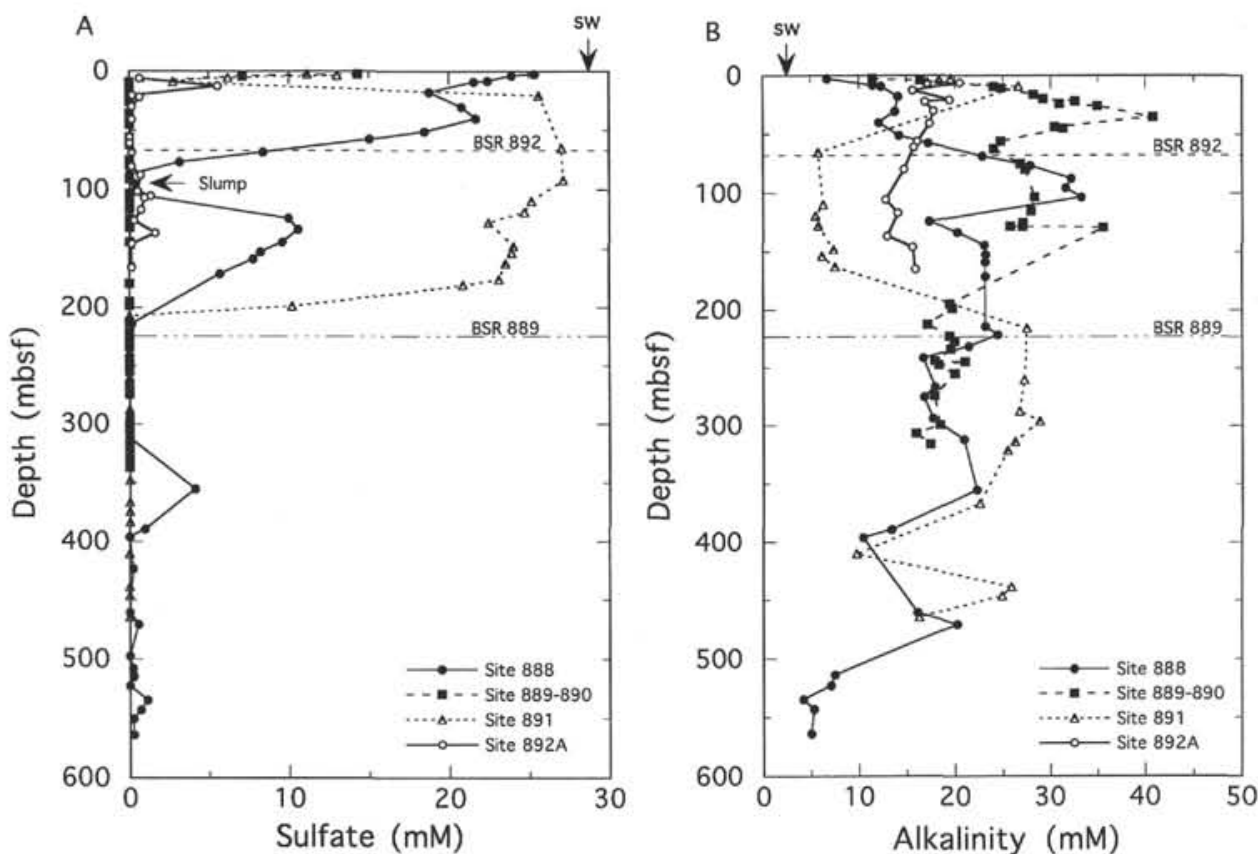

Figure 8. Depth profiles for (A) sulfate and (B) alkalinity concentrations in pore fluids from Sites 888, 889/890, 891, and 892. The arrow indicates seawater (SW) concentration (data from Westbrook, Carson, Musgrave, et al., 1994).

where at $<20 \mathrm{mbsf}$ sulfate is completely reduced, the moderate alkalinity values most likely reflect authigenic carbonate precipitation. The general overall steady decrease in alkalinity values with depth below 150-200 mbsf (Fig. 8B), is, however, mostly related to methane formation via bacterial $\mathrm{CO}_{2}$ reduction (e.g., Claypool and $\mathrm{Ka}-$ plan, 1974; Reeburgh, 1982; Whiticar et al., 1986; Suess and Whiticar, 1989) as implied by the $\delta^{13} \mathrm{C}_{\mathrm{DIC}}$ values, given in Whiticar et al. (this volume). Dissolved sulfate and alkalinity do not exhibit an inverse stoichiometric relationship because of the multiple reactions affecting pore fluid alkalinity (Fig. 2A, B).

Ammonia and dissolved phosphate also are important products of organic matter-fueled diagenesis. Because of their involvement in diagenetic reactions, (ammonia in clay minerals ion exchange and dissolved phosphate in carbonate-fluor-apatite (francolite) formation), neither is directly nor simply related to the stoichiometry of the precursor organic-matter $\mathrm{N}$ and $\mathrm{P}$.

Thus, the unorthodox inverse relationship between sedimentation rate and both organic matter content and type and rate of sulfate reduction (discussed above and also in Cragg et al., (this volume) and Whiticar et al. (this volume), which controls the rate, extent, and depth distribution of organic matter remineralization reactions, is a pronounced characteristic of organic matter-fueled diagenesis at the Cascadia Margin.

\section{Carbonate Diagenesis}

The $\mathrm{Ca} / \mathrm{Cl}$ and $\mathrm{Mg} / \mathrm{Ca}$ depth profiles (Fig. 9A, B) further accentuate the major influence sedimentation rate has on the geochemistry and diagenesis of the uppermost 200-300 mbsf of the Cascadia Margin sediments. Especially in the top $\sim 75 \mathrm{~m}$, the pore fluids of the slower sedimentation rate Sites $889 / 890$ (VI) and 892 (CO) have significantly lower $\mathrm{Ca} / \mathrm{Cl}$ and higher $\mathrm{Mg} / \mathrm{Ca}$ ratios than the corresponding seawater ratios (Fig. 9), indicating early $\mathrm{CaCO}_{3}$ (and/or some $\mathrm{Mg}$-Calcite) precipitation, followed by its partial dolomitization; authigenic carbonate is widespread in the Cascadia margin sediments.

The dolomitization process is kinetically enhanced by: (1) the high $\mathrm{Mg} / \mathrm{Ca}$ ratios of the pore fluids, from 7 to $>20$ (Fig. 9B), which are considerably higher than the seawater ratio of $5.4 ;(2)$ by the high alkalinities, of 15 to $40 \mathrm{mM}$, as compared with average seawater alkalinity of $\sim 2.4 \mathrm{mM}$; and (3) by the low to zero dissolved-sulfate concentrations below 10-20 mbsf (Baker and Kastner, 1981; Kastner et al., 1991). It can be represented by the overall reaction:

$$
\mathrm{CaCO}_{3}+\mathrm{Mg}^{2+}+2 \mathrm{HCO}_{3}{ }^{-}=\mathrm{CaMg}\left(\mathrm{CO}_{3}\right)_{2}+\mathrm{CO}_{2}+\mathrm{H}_{2} \mathrm{O}
$$

(A detailed discussion of the occurrence and geochemistry of authigenic carbonates at the Central Oregon Sites 891 and 892 is given in Sample and Kopf, this volume).

Evidence of upward vertical migration of a Ca-enriched fluid is recognizable in Figure 9A, at Sites 888, 889/890, and 892. Despite carbonate precipitation, $\mathrm{Ca}$ concentrations and $\mathrm{Ca} / \mathrm{Cl}$ ratios generally increase with depth. The increase is observed at Site 888 only below 450 mbsf, but at Site $889 / 890$ the $\mathrm{Ca} / \mathrm{Cl}$ ratios steeply increase below $130 \mathrm{mbsf}$, which is the depth of a prominent fluid conduit. At Site 892 , except for an initial rapid decrease, Ca concentrations increase with depth throughout the section. This mimics the vertical distributions of thermogenic hydrocarbons and headspace $\mathrm{C}_{1} / \mathrm{C}_{2}$ ratios, described in Westbrook, Carson, Musgrave, et al. (1994), and in Whiticar et al. (this volume). On the basis of an average geothermal gradient of $50^{\circ}$ to $70^{\circ} \mathrm{C} / \mathrm{km}$ (Table 1), the source of the thermogenic hydrocarbons must be at $>1 \mathrm{~km}$ burial depth (Westbrook, Carson, Musgrave, et al., 1994). The upward migration of a fluid enriched in dissolved $\mathrm{Ca}$, DIC in and thermogenic hydrocarbons favors the formation of epigenetic carbonates, with a vertical and spatial distribution that depends on the fluid-flow regime and also on sedimentation rate. In a confined fluid-flow regime epigenetic carbonates would be unevenly distributed, whereas, in a diffusive fluid-flow regime a more homogeneous distribution would be expected. In addition, at slower sedimentation rate sites, the epigenetic carbonates could permeate into shallower burial depths. Accordingly, two types of authigenic carbonates most likely form and coexist in the Cascadia Margin sediments; their relative importance and geochemistry depend on the evolution of the regional hydrology and sedimentology and should reflect the interplay between the geologic-hydrologic factors through time and space. The lack of a tight correspondence between the oxygen, carbon, and strontium isotope values of the authigenic carbon- 

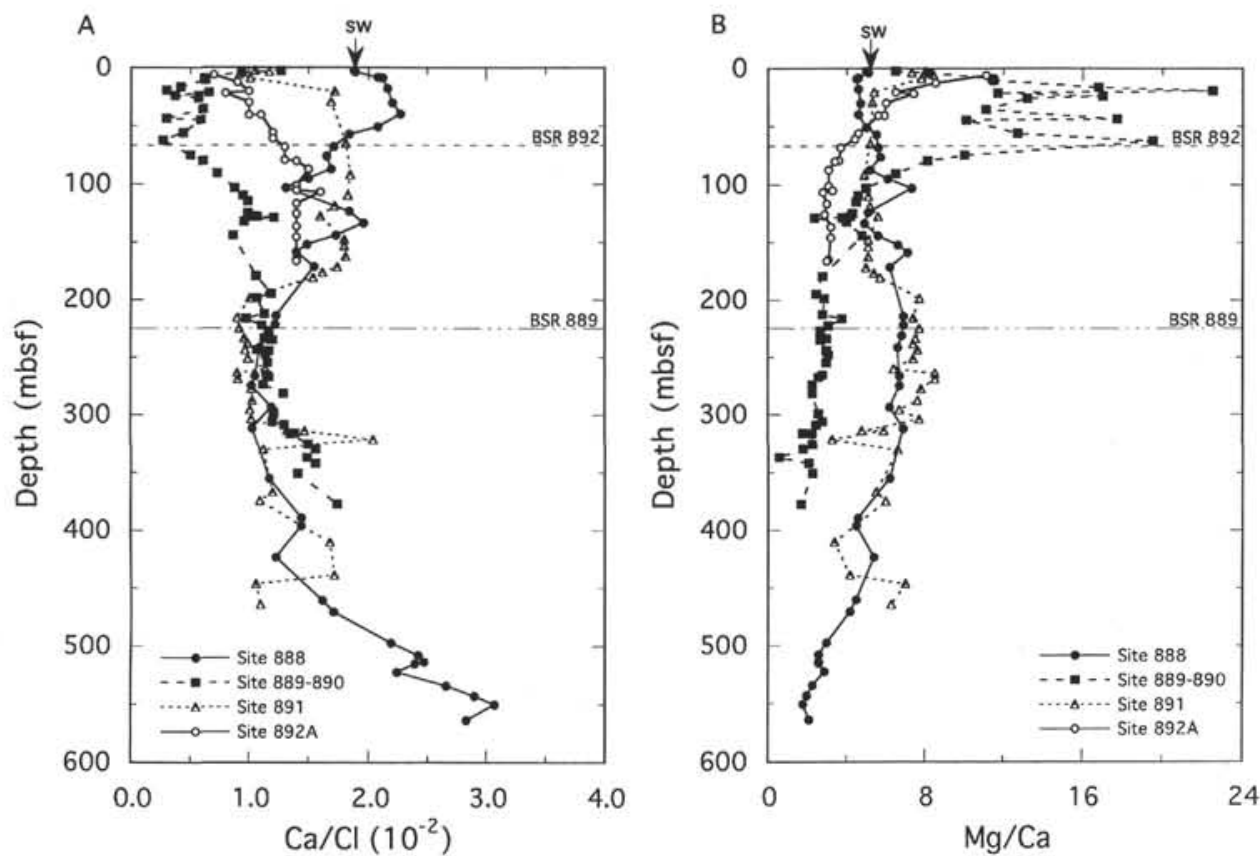

Figure 9. Depth profiles for (A) $\mathrm{Ca} / \mathrm{Cl}$ and (B) $\mathrm{Mg} / \mathrm{Ca}$ ratios in pore fluids of Sites $888,889 / 890,891$, and 892 . The arrow indicates seawater (SW) concentration (data from Westbrook, Carson, Musgrave, et al., 1994).

ates of Site 891, and to some extent of Site 892, reported in Sample and Kopf (this volume), and the $\delta^{18} \mathrm{O}$ and ${ }^{87} \mathrm{Sr} /{ }^{86} \mathrm{Sr}$ values of the in situ pore fluids (Kastner and Elderfield, this volume, and below) and the associated $\delta^{13} \mathrm{C}_{\mathrm{DIC}}$ values (Whiticar et al., this volume) might be explained, at least partially, by the complex origin of the authigenic carbonates in the Cascadia Margin, consisting of multi-generations and mixed origins.

\section{Geochemical Evidence for the Existence of Gas Hydrate}

Relating pore fluid chemistry to the nature and distribution of gas hydrate is the focus of this section. The discussion supplements the chapter on the general geochemistry of gas hydrates by Kastner et al. (this volume).

\section{BSRs and Gas Hydrate}

Prominent BSRs were drilled at two sites at the Cascadia Margin: at Site 889 (VI) where the BSR is located at $224 \mathrm{mbsf}$, and at Site 892 (CO) where it is located at 74 mbsf (marked in Figs. 2-7, 9) (Westbrook, Carson, Musgrave, et al., 1994). Solid gas hydrate was not recovered at either of these prominent BSRs. The $-1.4^{\circ} \mathrm{C}$ measured in a core from $\sim 8 \mathrm{~m}$ above the BSR Site 889 , indicating in situ gas hydrate dissociation, and the observed coincidence of very low porefluid $\mathrm{Cl}$ and very high headspace methane concentrations at the depth of both BSRs, strongly imply the presence of gas hydrate in situ, with methane as the dominant gas within the hydrate cages. Assuming bottom-water $\mathrm{Cl}$ concentration, the maximum $\mathrm{Cl}$ dilutions observed (36\% at Site 889 and $15 \%$ at Site 892 ) correspond to pore-space hydrate occupancies of $39 \%$ and $16 \%$, respectively. Because gas hydrate was not recovered, it is suggested that finely disseminated hydrate prevails above the BSR depths at these sites. The persistence of the zone of maximum $\mathrm{Cl}$ dilution below the BSR depth at Site 889 reflects a recent upward migration of the base of the stability field of gas hydrate (and BSR) by $\geq 120 \mathrm{~m}$, which most probably has occurred over the past 10 to 15 millennia at the Cascadia Margin, caused by tectonic processes and climate change (interglacial). Accordingly, a paleo-gas-hydrate 70-90-m-thick zone should exist below the mod- ern BSR. A more detailed discussion of the causes of the upward migration of the base of the gas hydrate stability is given in Kastner et al. (this volume).

Chloride is assumed to usually behave as a conservative component during diagenesis and metamorphism. Its concentration would increase by gas hydrate formation, or decrease by gas hydrate dissociation. Therefore, $\mathrm{Cl}$ concentration depth profiles are highly effective in detecting recently dissociated gas hydrate. Because methane hydrate is primarily composed of $\mathrm{CH}_{4}$ and $\mathrm{H}_{2} \mathrm{O}$, the only other significant geochemical consequences of its dissociation are: (1) the release of a large volume of methane (at standard temperature and pressure (STP), the volumetric ratio of $\mathrm{H}_{2} \mathrm{O} / \mathrm{CH}_{4}$ of a saturated methane hydrate $\mathrm{CH}_{4} \cdot 53 / 4 \mathrm{H}_{2} \mathrm{O}$, is $1 / 164$; Davidson et al., 1978; Sloan, 1990); (2) the release of fresh water; and (3) the enrichment of the pore waters in ${ }^{18} \mathrm{O}$ and $\mathrm{D}$. The formation of gas hydrate is analogous to the formation of sea ice. Experimentally derived fractionation factors for oxygen in the ice-water system range from 1.0031 to 1.0027 (e.g., O'Neil, 1968; Craig and Hom, 1968). For hydrogen it ranges from 1.0235 to 1.0195 (e.g., O'Neil, 1968; Craig and Hom, 1968; Arnason, 1969). The remaining chemical components will be diluted by the same proportions as the $\mathrm{Cl}$ dilution; thus, normalizing to chloride should not result chemical shifts.

The extent of $\mathrm{Cl}$ dilution may indicate the amount of gas hydrate present if the baseline chemistry is known, which is not the case at Sites 889 and 892 . On the basis of the geophysical evidence, provided in Westbrook, Carson, Musgrave, et al. (1994) and MacKay et al. (1994), at Site 889 above the BSR at least $15 \%$ of the pore space is occupied by gas hydrate. Geochemical mass balance calculations (Kastner et al., this volume) general agree with this estimate, that at this site at least one third of the observed $\mathrm{Cl}$ dilution above the BSR is due to gas hydrate dissociation, which corresponds to $\geq 15 \%$ pore space occupancy by gas hydrate.

At Site 892, a distinctly non-steady-state $\mathrm{Cl}$ concentration profile, characterized by closely spaced concentration reversals above the BSR depth arising from gas hydrate dissociation, is superimposed on an overall decrease with depth of $\mathrm{Cl}$ concentrations. Specific lithologic horizons, the "soupy" horizons described in Westbrook, Carson, Musgrave, et al. (1994) and Kastner et al. (this volume), favor 
the concentration of gas hydrate. Above the BSR at least $10 \%$ pore space occupancy with gas hydrate is indicated.

At both Sites 889 and 892 the in situ measured borehole temperatures at the seismic BSRs are lower by approximately $2^{\circ} \mathrm{C}$ than the calculated temperatures for the base of a pure $\mathrm{H}_{2} \mathrm{O}$-pure $\mathrm{CH}_{4}$ hydrate stability field at corresponding pressures. Addition of gases such as ethane, $\mathrm{CO}_{2}$, or $\mathrm{H}_{2} \mathrm{~S}$ further increases the hydrate stability temperature at corresponding pressures. The measured temperatures, howev$\mathrm{er}$, broadly correlate with the base of the stability field of a seawater$\mathrm{CH}_{4}$ hydrate (e.g., Dickens and Quinby-Hunt, 1994).

\section{The $\mathrm{CH}_{4}-\mathrm{H}_{2} \mathrm{~S}$ Hydrate}

Solid gas hydrate was recovered at Site 892 at 2-19 mbsf. The hydrate occurs as $0.5-1.5 \mathrm{~cm}$ long platy crystals or crystal aggregates mostly disseminated irregularly, with higher concentrations in patchy zones, in specific thin layers, and/or veinlets that are parallel or oblique to bedding. Only one $\sim 2$-cm-thick pure hydrate layer was recovered at $\sim 18 \mathrm{mbsf}$. The measured core temperatures ranged from $\sim 2^{\circ}$ to $-1.8^{\circ} \mathrm{C}$. This mixed gas-hydrate contains $\mathrm{CH}_{4}$ and up to $10 \%$ of the gas released is $\mathrm{H}_{2} \mathrm{~S}$. It also contains minor amounts of ethane and some $\mathrm{CO}_{2}$ (Kastner et al., this volume; Kastner et al., unpubl. data). The $\mathrm{C}$ and $\mathrm{H}$ isotopic compositions of hydrate $\mathrm{CH}_{4}$, of $-64.5 \%$ (PDB) and $-197 \%$ (SMOW), and $-67.5 \%$ (PDB) and $-199 \%$ (SMOW) suggest a mixed bacterial-thermogenic, although mostly bacterial, origin (Kastner and Elderfield, this volume; Kastner et al., this volume). The sulfur isotopic composition of its $\mathrm{H}_{2} \mathrm{~S},+27.4 \%$, indicates that it formed where little residual isotopically heavy sulfate remained; and its $\mathrm{H}_{2} \mathrm{O}$ oxygen isotope value of $+2.77 \%$ (SMOW) is close to that of sea ice (Craig and Hom, 1968). Based on the isotopic compositions of the pure hydrate and the limited depth distribution of the $\mathrm{CH}_{4}-\mathrm{H}_{2} \mathrm{~S}$ hydrate, from 2 to $19 \mathrm{mbsf}$, it is suggested that a fluid rich in $\mathrm{CH}_{4}$ and containing ethane, originating from an intermediate depth, is migrating along a low-angle fault and mixing with the in situ pore fluid within the active sulfate reduction zone. Its unusual composition together with its confined occurrence, only above $19 \mathrm{mbsf}$, indicate mixing with an external fluid source, and that this hydrate system must be geologically young (Kastner et al., unpubl. data).

\section{CONCLUSION}

The geochemical depth profiles presented in Kastner and Elderfield (this volume), and in Westbrook, Carson, Musgrave, et al. (1994), together with the temperature depth profiles (Westbrook, Carson, Musgrave, et al., 1994), indicate that fluid flow in the Cascadia Convergent Margin is pervasive. Although diffusive flow predominates at the Vancouver Island sites, confined flow exists. The latter is mostly stratigraphically controlled. It is probably induced by differential tectonic compaction of the sediments; the Site 889 fluid conduit at $130 \mathrm{mbsf}$ is an example. At the Central Oregon sites, although fracture and fault-controlled confined fluid flow is the dominant hydrologic regime, diffusive vertical fluid migration via tectonic compaction is also indicated by the geochemical depth-profiles.

Superimposed on the non-regional but local geochemical signatures, produced by in situ fluid-sediment reactions, is a strong and important regional signature arising from the mixing with a deep-seated fluid source, situated at $>1.5$ but $<4 \mathrm{~km}$ depth that is common to all sites. The extent of mixing between this and the in situ diagenetic pore fluid is spatially variable.

Organic matter-fueled anoxic diagenesis is widespread. Carbonates and sulfides are the important diagenetic mineral products. The upward-migrating fluid from the deeper source, which is enriched in $\mathrm{Ca}, \mathrm{CH}_{4}$, and DIC, favors epigenetic carbonate precipitation. Therefore, two types of authigenic carbonates should exist; they may be intimately intergrown. One is a product of diagenesis controlled by bacterial processes, the other is a product of epigenesis, controlled by tectonic and thermal processes.

Although not recovered, a primarily methane hydrate occupies at least $15 \%$ of the pore space above the BSR depth of Site 889 and, at least $10 \%$ of the pore space above the BSR depth at Site 892. The gas hydrate recovered at 2-19 mbsf at Site 892 is a mixed $\mathrm{CH}_{4}-\mathrm{H}_{2} \mathrm{~S}$ hydrate; up to $10 \%$ of the hydrate gas is $\mathrm{H}_{2} \mathrm{~S}$. It forms from a methanerich fluid containing some ethane that originates at an intermediate depth, and migrates along a low-angle fault into the sulfate reduction zone of Site 892. Its confinement to the 2 to 19 mbsf depth interval indicates that it is geologically a young feature.

\section{ACKNOWLEDGMENTS}

We greatly appreciate the Leg 146 shipboard scientists for stimulating dialogues, we thank the technicians for their assistance, specifically the ODP chemistry technicians Anne Pimmel and Dennis K. Graham for their skillful help in the shipboard geochemical work, and the staff and drilling crews aboard the JOIDES Resolution for their cooperation. We especially thank Dr. G. Lugmair for his assistance in the Sr isotope analyses, and Dr. M. Wahlen and B. Deck for their assistance in the methane isotope analyses. The manuscript greatly benefitted from an anonymous review and comments from the ODP editorial staff. This research was supported by a JOI-USSAC grant and by an NSF grant OCE 91-15784 to M. Kastner.

\section{REFERENCES}

Arnason, B., 1969. Equilibrium constant for the fractionation of deuterium between ice and water. J. Phys. Chem., 73:3491-3494.

Baker, P.A., and Kastner, M., 1981. Constraints on the formation of sedimentary dolomite. Science, 213:215-216.

Bray, C.J., and Karig, D.E., 1985. Porosity of sediments in accretionary prisms and some implications for dewatering processes. J. Geophys. Res., 90:768-778.

Carson, B., Seke, E., Paskevich, V., and Holmes, M.L., 1994. Fluid expulsion sites on the Cascadia accretionary prism: mapping diagenetic deposits with processed GLORIA imagery. J. Geophys. Res., 99:11959-11969.

Carson, B., Suess, E., and Strasser, J.C., 1990. Fluid flow and mass flux determinations at vent sites on the Cascadia margin accretionary prism. $J$. Geophys. Res., 95:8891-8897.

Claypool, G.E., and Kaplan, I.R., 1974. The origin and distribution of methane in marine sediments. In Kaplan, I.R. (Ed.), Natural Gases in Marine Sediments: New York (Plenum), 99-139.

Cochrane, G.R., MacKay, M.E., Moore, G.F., and Moore, J.C., 1994. Consolidation and deformation of sediments at the toe of the central Oregon accretionary prism from multichannel seismic data. In Westbrook, G.K., Carson, B., Musgrave, R.J., et al., Proc. ODP, Init. Repts., 146 (Pt. 1): College Station, TX (Ocean Drilling Program), 421-426.

Craig, H., 1961. Isotopic variations in meteoric waters. Science, 133:17021703.

Craig, H., and Hom, B., 1968. Relationship between deuterium, oxygen-18 and chlorinity in the formation of sea ice. Trans. Am. Geophys. Union, 49:216-217.

Davidson, D.W., El-Defrawy, M.K., Fuglem, M.O., and Judge, A.S., 1978. Natural gas hydrates in northern Canada. Proc. 3rd Int. Conf. Permafrost, 3:937-943.

Davidson, D.W., Leaist, D.G., and Hesse, R., 1983. Oxygen-18 enrichment in water of a clathrate hydrate. Geochim. Cosmochim. Acta, 47:22932295.

Dickens, G.R., and Quinby-Hunt, M.S., 1994. Methane hydrate stability in seawater. Geophys. Res. Lett., 21:2115-2118.

Edmond, J.M., Measures, C., McDuff, R.E., Chan, L.H., Collier, R., and Grant, B., 1979. Ridge crest hydrothermal activity and the balances of the major and minor elements in the ocean: the Galapagos data. Earth Planet. Sci. Lett., 46:1-18.

Hodell, D.A., Mead, G.A., and Mueller, P.A., 1990. Variation in the strontium isotopic composition of seawater ( $8 \mathrm{Ma}$ to present): implications for chemical weathering rates and dissolved fluxes to the oceans. Chem. Geol. (Isotope Geosci. Sect.), 80:291-307. 
Hyndman, R.D., and Davis, E.E., 1992. A mechanism for the formation of methane hydrate and seafloor bottom-simulating reflectors by vertical fluid expulsion. J. Geophys. Res., 97:7025-7041.

Kastner, M., Elderfield, H., and Martin, J.B., 1991. Fluids in convergent margins: what do we know about their composition, origin, role in diagenesis and importance for oceanic chemical fluxes? Philos. Trans. $R$. Soc. London A, 335:243-259.

Kulm, L.D., and Suess, E., 1990. Relationship between carbonate deposits and fluid venting: Oregon accretionary prism. J. Geophys. Res., 95:8899-8915.

Kulm, L.D., Suess, E., Moore, J.C., Carson, B., Lewis, B.T., Ritger, S.D., Kadko, D.C., Thornburg, T.M., Embley, R.W., Rugh, W.D., Massoth, G.J., Langseth, M.G., Cochrane, G.R., and Scamman, R.L., 1986. Oregon subduction zone: venting, fauna, and carbonates. Science, 231:561566.

Lawrence, J.R., Gieskes, J.M., and Broecker, W.S., 1975. Oxygen isotope and cation composition of DSDP pore waters and the alteration of Layer II basalts. Earth Planet. Sci. Lett., 27:1-10.

MacKay, M.E., Jarrard, R.D., Westbrook, G.K., and Hyndman, R.D., 1994. Origin of bottom-simulating reflectors: geophysical evidence from the Cascadia accretionary prism. Geology, 22:459-462.

Martin, J.B., Kastner, M., and Elderfield, H., 1991. Lithium: sources in pore fluids of Peru slope sediments and implications for oceanic fluxes. Mar. Geol., 102:281-292.

Moore, J.C., Orange, D., and Kulm, L.D., 1990. Interrelationship of fluid venting and structural evolution: Alvin observations from the frontal accretionary prism. J. Geophys. Res., 95:8795-8808.

Müller, P.J., and Suess, E., 1979. Productivity, sedimentation rate, and sedimentary organic matter in the oceans, I. Organic carbon preservation. Deep-Sea Res. Part A, 26:1347-1362.

O'Neil, J.R., 1968. Hydrogen and oxygen isotope fractionation between ice and water. J. Phys. Chem., 72:3683-3684.
Reeburgh, W.S., 1982. A major sink and flux control for methane in marine sediments: anaerobic consumption. In Fanning, K.A., and Manheim, F.T. (Eds.), The Dynamic Environment of the Ocean Floor: Lexington, MA (D.C. Heath), 203-217.

Ritger, S., Carson, B., and Suess, E., 1987. Methane-derived authigenic carbonates formed by subduction-induced pore water expulsion along the Oregon/Washington margin. Geol. Soc. Am. Bull., 98:147-156.

Seyfried, W.E., Jr., Janecky, D.R., and Mottl, M.J., 1984. Alteration of the oceanic crust: implications for geochemical cycles of lithium and boron. Geochim. Cosmochim. Acta, 48:557-569.

Sloan, E.D., 1990. Clathrate Hydrates of Natural Gasses: New York (Marcel Dekker).

Suess, E., and Whiticar, M.J., 1989. Methane-derived $\mathrm{CO}_{2}$ in pore fluids expelled from the Oregon subduction zone. Palaeogeogr., Palaeoclimatol., Palaeoecol., 71:119-136.

Tobin, H.J., Moore, J.C., and Moore, G.F., 1994. Fluid pressure in the frontal thrust of the Oregon accretionary prism: experimental constraints. Geology, 22:979-982.

Westbrook, G.K., Carson, B., Musgrave, R.J., et al., 1994. Proc. ODP, Init. Repts., 146 (Pt. 1): College Station, TX (Ocean Drilling Program).

Whiticar, M.J., Faber, E., and Schoell, M., 1986. Biogenic methane formation in marine and freshwater environments: $\mathrm{CO}_{2}$ reduction vs. acetate fermentation-isotope evidence. Geochim. Cosmochim. Acta, 50:693709 .

Date of initial receipt: 6 March 1995

Date of acceptance: 15 May 1995

Ms 146SR-243 